\title{
WEB-BASED HEART DISEASE DIAGNOSIS SYSTEM WITH FORWARD CHAINING METHOD (CASE STUDY OF IBNU SINA ISLAMIC HOSPITAL)
}

\author{
Refni Wahyuni ${ }^{1}$ \\ Yuda Irawan ${ }^{2}$ \\ STMIK Hang Tuah Pekanbaru \\ refniabid@gmail.com¹, yudairawan89@ gmail.com²
}

\begin{abstract}
Expert systems are computer-based applications that are used to solve problems thought by experts. The benefits of expert systems are to find solutions to problems that occur in various fields including medicine and medical. The problem that often occurs is the problem of public knowledge of the initial problems of heart disease and the lack of public attention to heart health. From this problem, the writer wants to raise the title "Expert System of Web-Based Heart Disease Diagnosis with Forward Chaining Method (Case Study of Ibnu Sina Islamic Hospital)". The purpose of this system is so that people can understand, understand the facts of heart disease. The method used in making this system is forward chaining because this method is a punishment starting from the fact that it contains sentences that are received. The output of this system is a diagnosis of heart disease, as well as providing recommendations for how to treat the disease.
\end{abstract}

Keywords: Forward Chaining, Expert System, Heart Disease.

\section{INTRODUCTION}

Health is the most valuable treasure possessed by every human being, most people do not care about the importance of health for life. Nowadays, it is easier to find more knowledge about health, by reading books, consulting with doctors, or using technology media. The hospital is now using a computer to improve hospital performance. The consultation process so far is to involve doctors directly with patients, this causes laziness or forget to consult because it gets community participation, so that the number of sufferers of heart disease increases. Public relations will affect the number of sufferers of heart disease.

One alternative to overcome these challenges is the Expert System for Diagnosing Heart Disease Based on Web Using the Forward Chaining Method. Forward chaining method is one of the many methods that exist in artificial intelligence, forward chaining method is to carry out the process starting from a collection of data, processed in accordance with the rules applied and obtained conclusions as a solution of the agreement. The system will repeat it until it gets the right result.

The purpose of this study is to create an Expert System to Diagnose Heart Disease Based on Web Using the Forward Chaining Method so as to facilitate the public in diagnosing heart disease.

\section{LITERATURE REVIEW}

In general, an expert system is a system that requires human knowledge for computers, so that computers can solve problems as is usually done by experts (Kusumadewi, 2003: 109). According to Kusrini (2008: 3) Expert systems are computer-based applications that are used to solve problems thought by experts.

According to Kusrini (2008: 8) Forward chaining means using a set of rules of action. In this method, the data is used to determine which rules to run, and then the rules are run. Maybe the process of adding data to working memory. The process is repeated until an outcome is found (Wilson, 1998). Forward chaining inference method is suitable to be used to overcome the problem of control (Control) and forecasting (prognosis) (Giarattano and Riley, 1994).

Heart disease is one of the leading causes of death in medical history. Given its function which is vital for life, maintaining heart health is very important. One of them is to get to know the early signs and symptoms of heart disease so that we can anticipate it from the beginning. (source: dinkes.sumbarprov.go.id). 
Types of heart disease :

1. Acute Myocardial Infarction is According to Sjaifoellah Noer (1996: 1098) Acute myocardial infarction is myocardial necrosis due to impaired blood flow to the heart muscle.

2. Hypertensive Heart is According to Sjaifoellah Noer (1996: 1129) Hypertensive is a disorder characterized by an increase in peripheral resistance. This causes an increase in cardiac burden resulting in left ventrical hypertrophy as a process of compensation / adaptation.

3. Heart Failure is According to Sjaifoellah Noer (1996: 975) Definition of heart failure according to Braunwald, heart failure is a pathophysiological state of abnormalities in heart function resulting in heart failure to pump blood to meet the needs of tissue metabolism or its ability to only exist if accompanied by elevated left ventricular filling pressure . Defined according to Packer, coongestive heart failure is a complicated clinical syndrome characterized by abnormalities in left ventrical function and abnormalities in neurohormonal regulation, accompanied by intolerance of physical ability to work (effort intolerance), fluid retention and shorter life span (reduced longevity).

4. Ischemic heart is according to Sjaifoellah Noer (1996: 954) Ischemic is an imbalance between the need for cardiac perfusion and oxygenated blood supply by the coronary arteries.

5. Cardiac arrhythmias are the collective term for all disorders of the heart rhythm outside the normal sinus rhythm.

Research conducted by Refni Wahyuni (2019) about Application Of Expert System For Diagnosis Of Campake Disease And Prevention With Web-Based Forward Chaining Methods, this study discusses the expert system of measles disease diagnosis and its prevention by using forward chaining method. Data collection methods using 2 techniques, namely literature study, namely by using books, journals and articles related to the problem, while the second method is to make observations directly to the clinic and meet with experts. This application can help the wider community in diagnosing measles and provide prevention solutions, besides this application also provides some information related to the symptoms of measles and its solutions.

A study conducted by Yulisman and Monalisa (2019) with the title of an expert system in diagnosing dengue fever (DHF) using a web-based forward chaining method, this study discusses the early diagnosis of dengue fever, because dengue is a contagious and dangerous disease that can cause death. the results of this study are to provide information and solutions about dengue fever based on the knowledge and abilities of doctors.

A study conducted by Bagus Feri Yanto and his colleagues entitled Application of Expert System for Diagnosis of Diseases in Children Under Five Using the Forward Chaining Method in 2017. This study aims to create an expert system application diagnosis of disease in toddlers based on mobile. This research consists of three stages. The first stage is the collection of data and information from the Integrated Management of Underfives (MTBS) and interviews with Midwives. From the collection of data and information found the facts of the disease, complaints, symptoms and suggestions handling. The second step is making rules with 18 diseases. The third stage is the implementation of a mobile-based expert system application with features of disease diagnosis, history of diagnosis and collection of diseases. Expert system applications are made that can diagnose diseases and provide treatment recommendations. The results of the evaluation of 50 trial data resulted in an accuracy rate of $82 \%$, where 41 were diagnosed correctly and 9 were diagnosed incorrectly.

Research conducted by Nanda Jarti and Roden Trisno (2017) entitled the expert system for diagnosing allergic diseases in children web-based with the method of forward chaining in Batam, in the design of this expert system is a system used to diagnose allergic diseases in children. Diagnosis process begins by the way the user answers the questions in the form of symptoms suffered by the user. the results of this study include the application of an expert system designed to be able to diagnose allergic diseases in children based on the symptoms inputted by the user. 


\section{Research Methods}

To get good research results there needs to be objective data and information. The research methodology use is as follows:

1. Literature Study

The process of gathering several journals related to the research topic and making literature review as a guide in writing the background of the problem.

2. Data Collection

The data collection stage is carried out by:

a. Observation

At this stage the authors made observations to the Islamic Hospital of Ibn Sina in the Medical Records section. Researchers make observations on existing data, relating to the topic being raised.

b. Literature

At this stage the researcher looks for references in the form of books, journals and scientific papers related to the topic being studied.

3. Data Analysis

Data analysis is the process of analyzing data obtained from Ibnu Sina Islamic Hospital. Data analysis describes the current system and the proposed system.

4. System Design

After the data analysis process is carried out, the next process is system design, global system design and detailed system design.

5. Coding

Coding expert system for diagnosing heart disease using the programming language PHP and MySQL as a database. While the application used is Macromedia Dreamweaver 8

6. Testing

The system testing process is to prove the system runs as expected.

\section{RESEARCH RESULTS AND DISCUSSION}

User Pages

On this page there is a Home menu, Disease data menu, Consultation, Help, and Admin menu.

1. Display the Home Menu Page

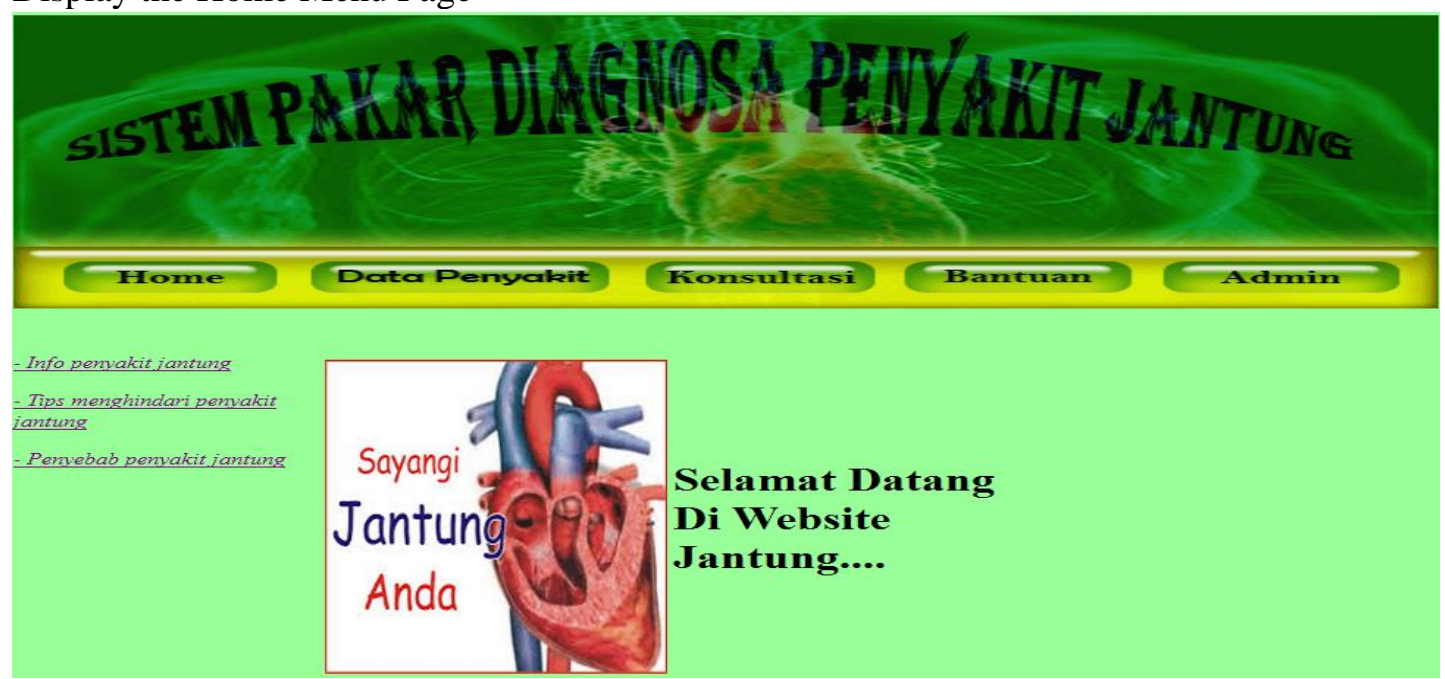

Figure 1. Display the Home menu page

2. Disease Data Menu Display 


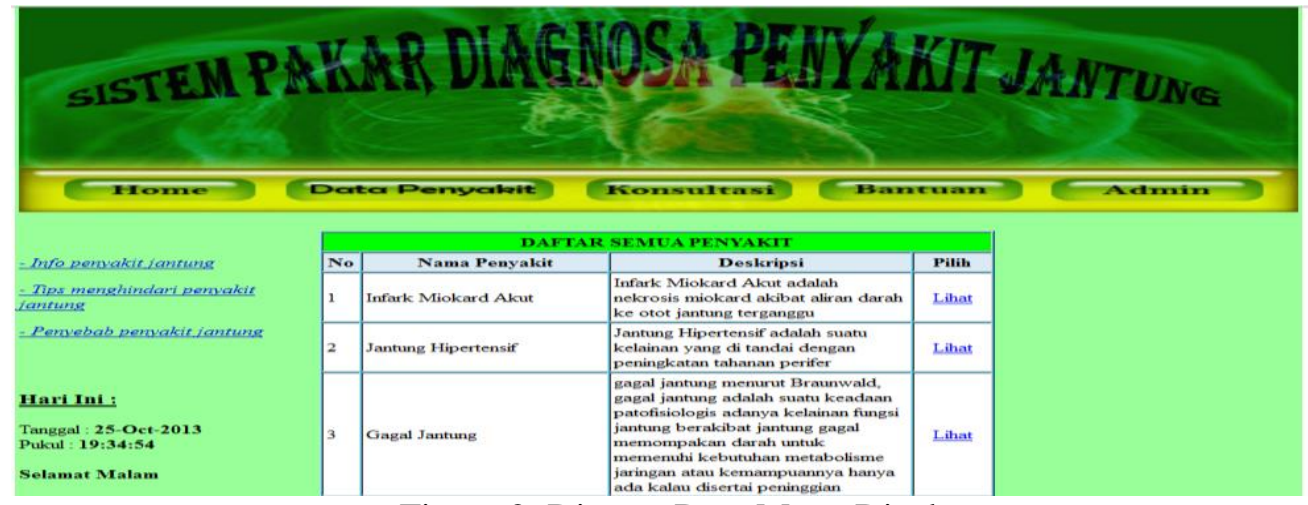

Figure 2. Disease Data Menu Display

3. Consultation Menu Page

On this page, users can do consultations by answering questions given by the system. Before the consultation process is carried out, a user must fill in patient data first.

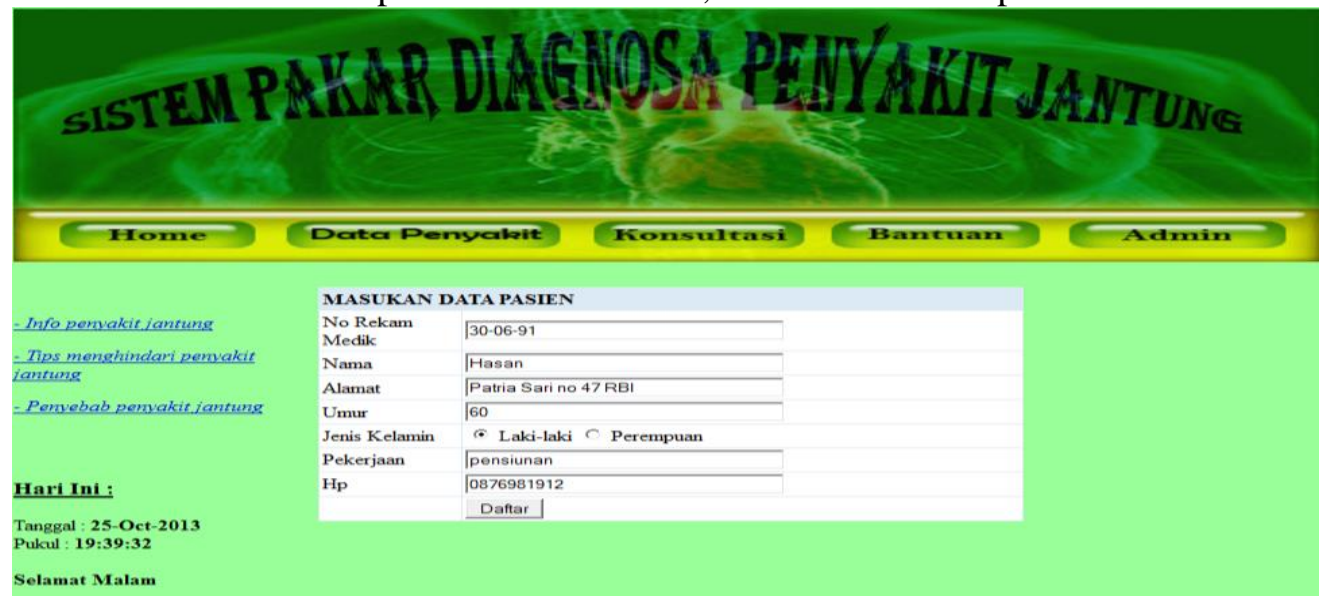

Figure 3. List page

On this page the patient is expected to answer the symptoms asked by the application, while the answer given is yes or no, after question 1 is answered, then the next question will automatically be displayed until the question is complete.

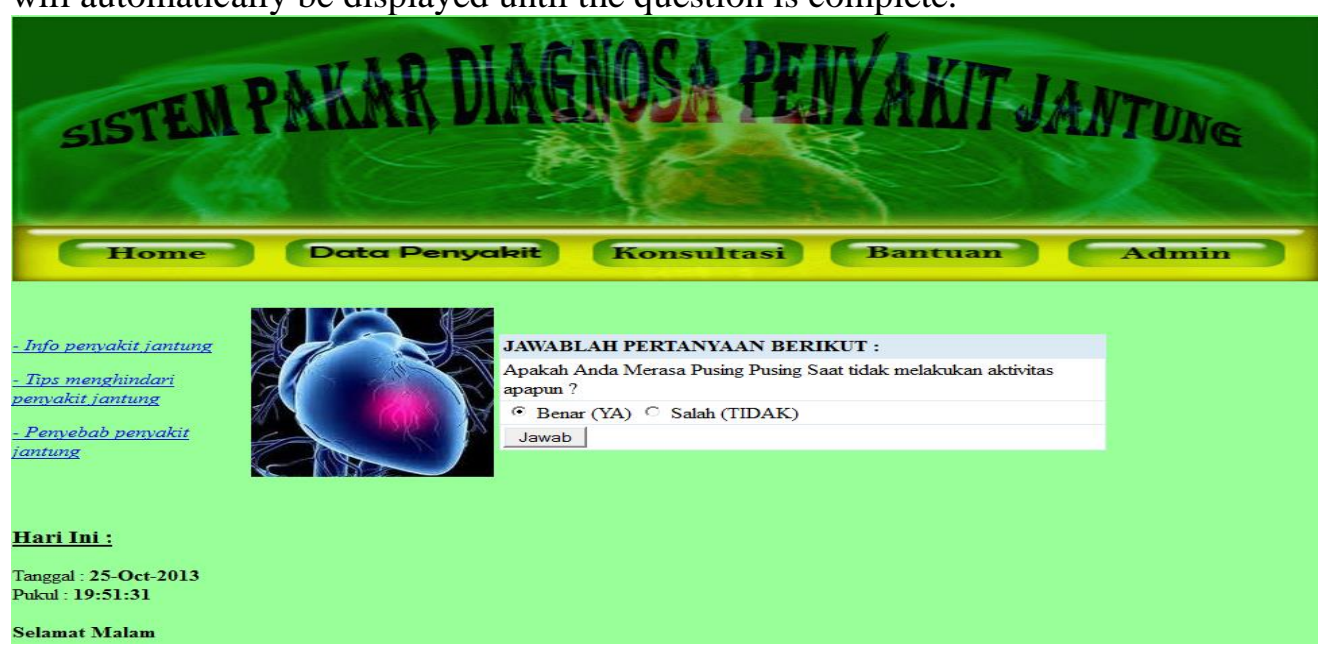

Figure 4. Consultation Menu Page

In the picture below, the patient diagnosis results will be seen, patient data, the results are in the form of the illness, symptoms of the disease, information about the disease and history. 


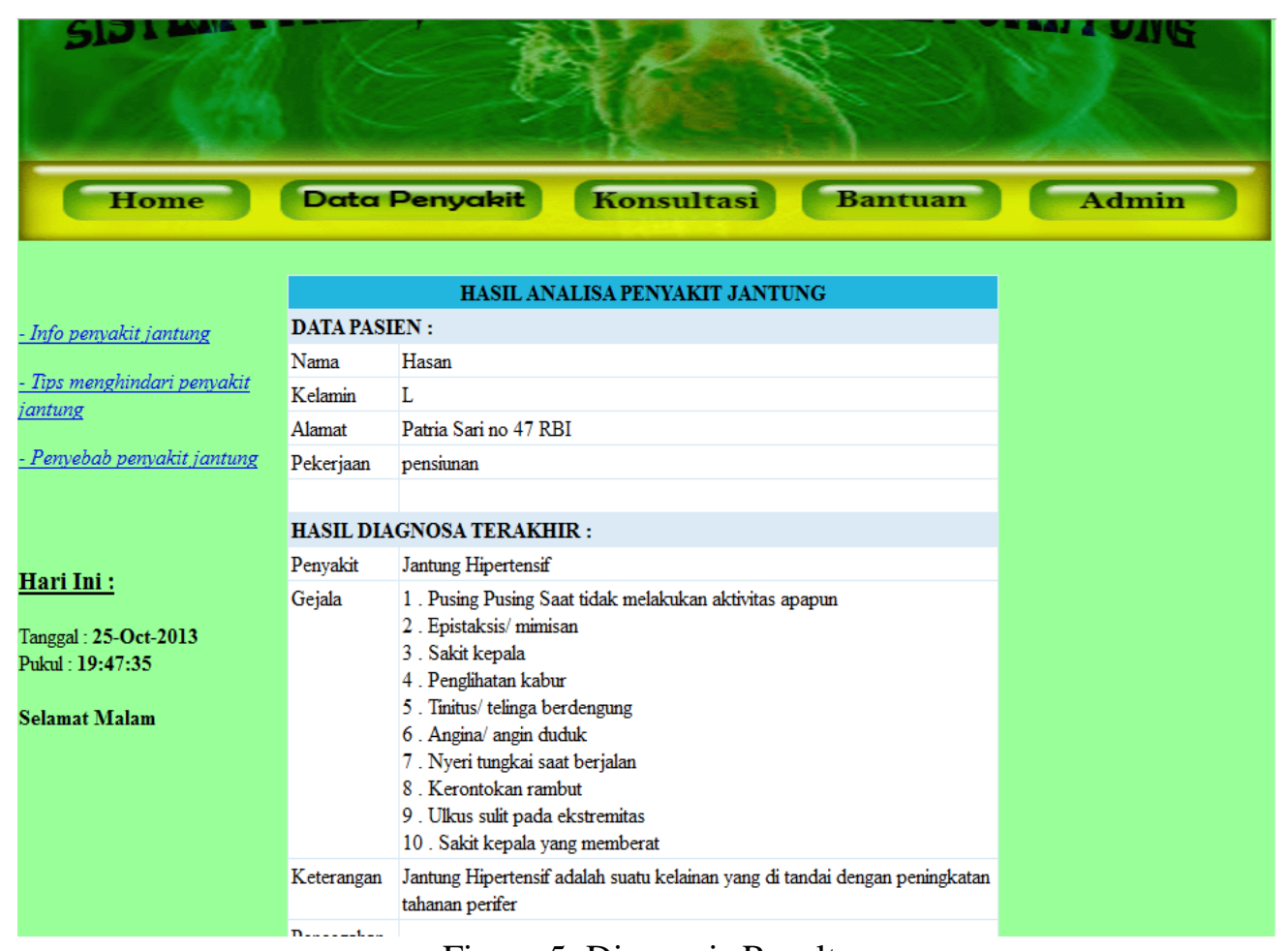

Figure 5. Diagnosis Results

Admin menu is for admins who want to enter the admin page, when the admin menu is clicked, a login will appear to enter the admin page.

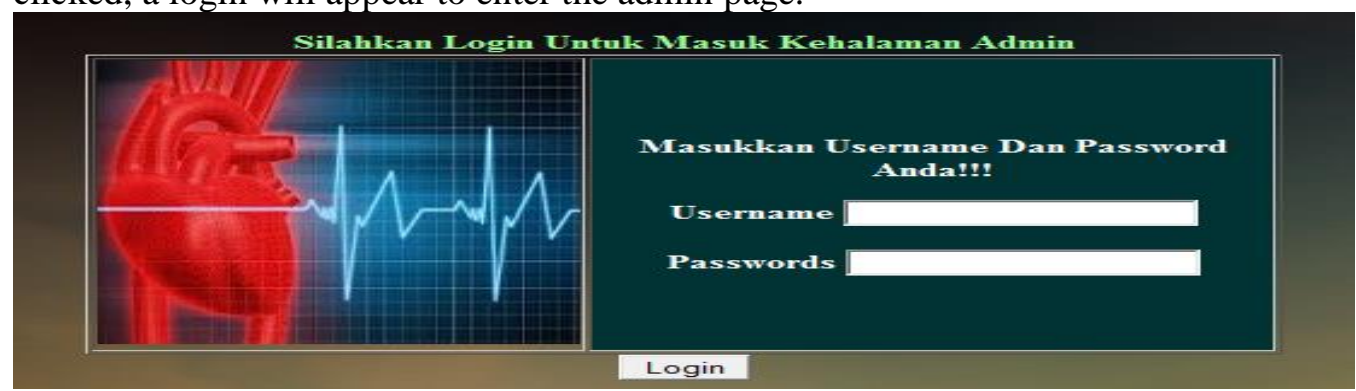

Figure 6. Admin Login page

The Disease Menu page is for inputting, changing and removing types of disease.

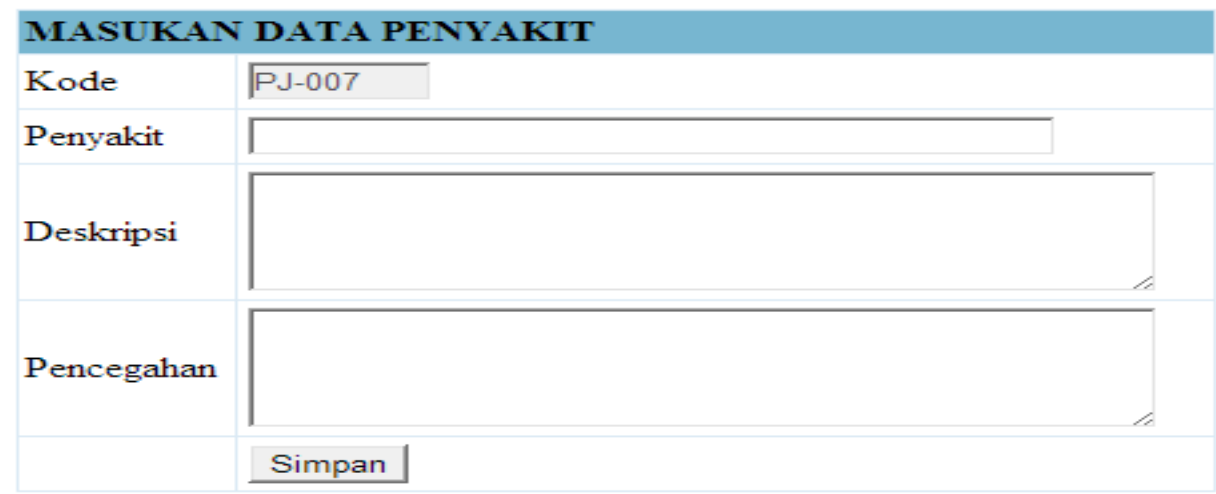

Figure 7. Disease Input Page

The Symptoms Input Menu page is for inputting, changing and removing symptoms.

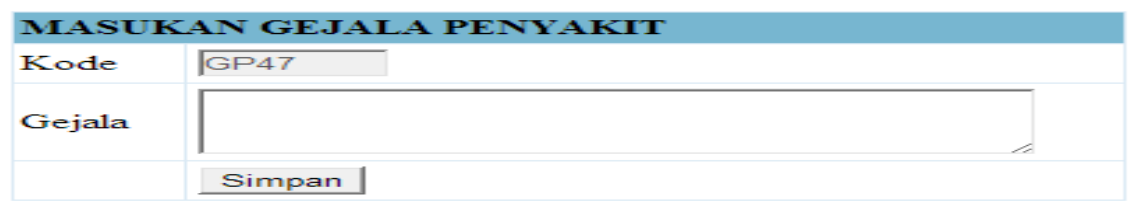


Figure 8. Input Symptoms

The Relation Menu page contains the relationship between disease and symptoms.

RELASI GEJALA DAN PENYAKIT

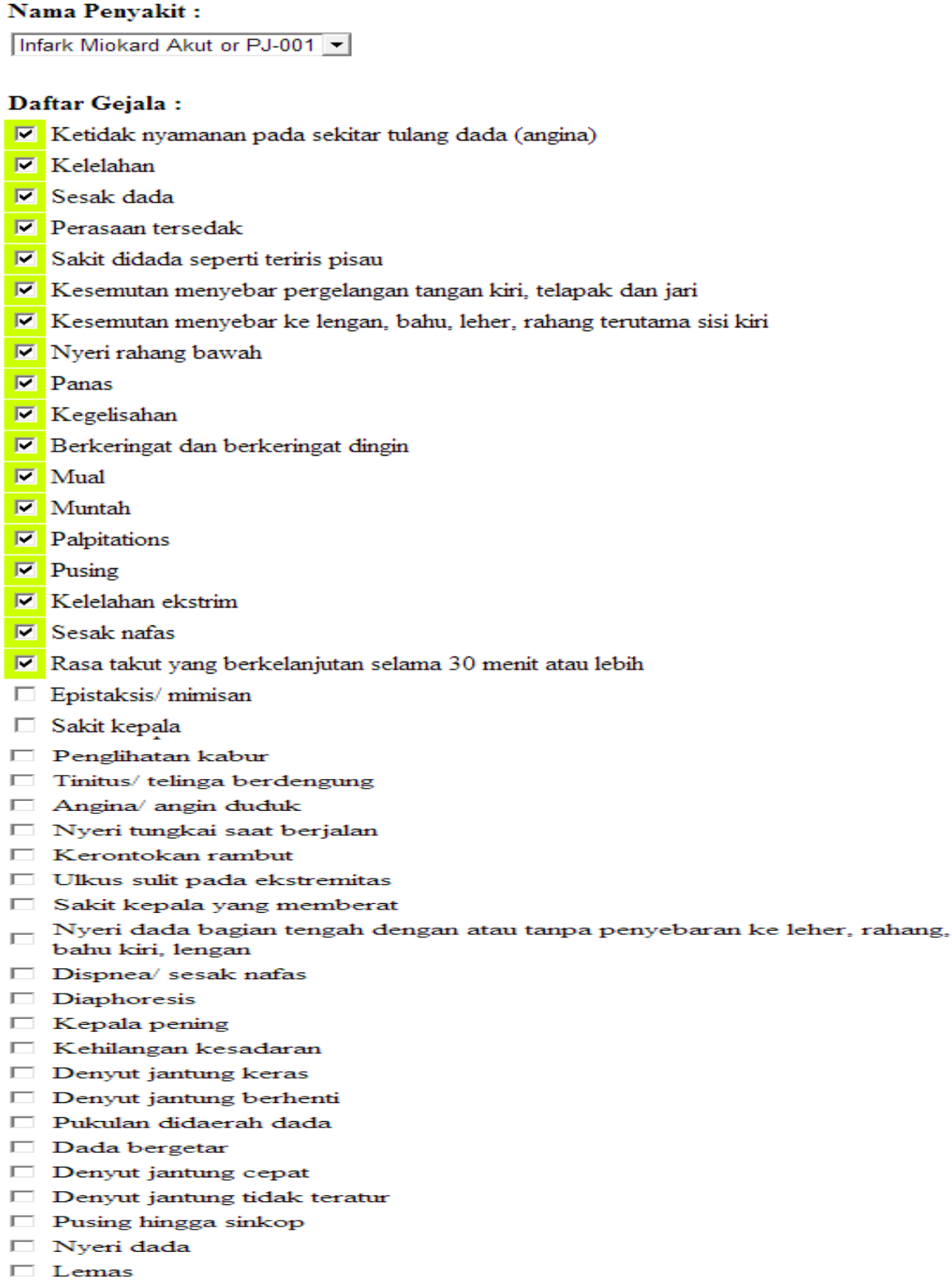

Figure 9. Relation Input

In the following figure is a report on the results of diagnoses of patients who make the diagnosis using an expert system application. 


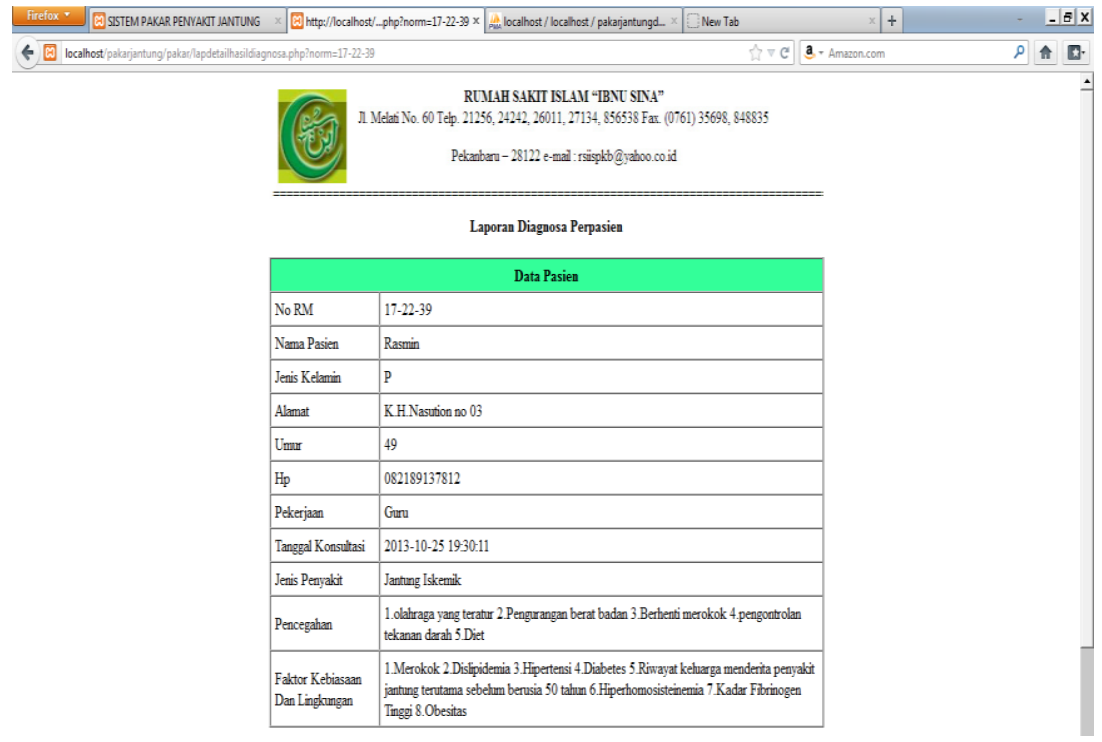

Figure 10. Patient Diagnosis Report

\section{CONCLUSION \& SUGGESTION \\ Conclusion}

Based on the analysis of the results of the discussion and answer from the problem formulation, it can be concluded:

1. This expert system will make it easier for users to recognize the early symptoms of heart disease, and increase user knowledge about heart disease

2. Expert system created using Depth First Search by analyzing all existing data

3. This expert system can register once for one diagnostic process

4. This expert system is created using the forward chaining inference method, where the user will be asked questions in the form of symptoms that are felt, the user will answer YES or NO. From these answers, the system will provide a conclusion in the form of illness and prevention

5. This expert system has not been able to produce a type of heart disease based on the estimated $\%$ of each heart disease

\section{Suggestions}

From these conclusions, several suggestions can be made that will help to further develop the expert system.

1. Data needed for types of heart disease so that the information needed will be more extensive and more numerous

2. On the admin menu, if there is a need for more complicated data, the admin must design a more flexible tree so that it can facilitate the admin in doing system management

\section{REFERENCES}

Giarattano, J. \& Riley, G. (1994). Expert system principles and Programming. Boston: PWS Publishing Company.

Jarti, N., \& Trisno, R. (2017). Sistem Pakar Diagnosa Penyakit Alergi pada Anak Berbasis Web dengan Metode Forward Chaining di Kota Batam. Jurnal Edik Informatika, 3(2), 197205.

Kusrini. (2008). Aplikasi Sistem Pakar Menentukan Faktor Kepastian Pengguna Dengan Metode Kuantifikasi Pertanyaan. Andi, Yogyakarta

Kusumadewi, Sri (2003). Artificial Intellegence Tehnik dan aplikasinya. Yogyakarta : Graha Ilmu.

Kusrini. (2008). Aplikasi Sistem Pakar. Penerbit Andi, Yogyakarta.

Sjaifoellah, N. (2004). Buku Ajar Ilmu Penyakit Dalam. Jilid I. Edisi III. Jakarta: FKUI. 
Wahyuni, R. (2019). Jurnal Aplikasi Sistem Pakar Untuk Diagnosa Penyakit Campak Dan Pencegahan Dengan Metode Forward Chaining Berbasis Web. Jurnal Ilmu Komputer, $8(2), 53-59$.

Wilson, B. (1998). The AI Dictionary, retrieved from : URL: http://www.cse.unsw.edu.au/ billw/aidict.htm

Yanto, B. F., Werdiningsih, I., \& Purwanti, E. (2017). Aplikasi Sistem Pakar Diagnosa Penyakit Pada Anak Bawah Lima Tahun Menggunakan Metode Forward Chaining. Journal of Information Systems Engineering and Business Intelligence, 3(1), 61-67.

Yulisman \& Monalisa. (2019). Sistem Pakar Mendiagnosa Penyakit Demam Berdarah Dengue (Dbd) Menggunakan Metode Forward Chaining Berbasis Web. Jurnal Ilmu Komputer, $8(2), 34-46$. 